A R CHAEOLOGIA:

O R

MISCELLA NEOUS TR ACTS

RELATING TO

A N T I Q U I T Y.

V O L. II. 


\section{A R CHAEOLOGIA:}

O R

MISCELLANEOUS TRACTS

RELATING TO

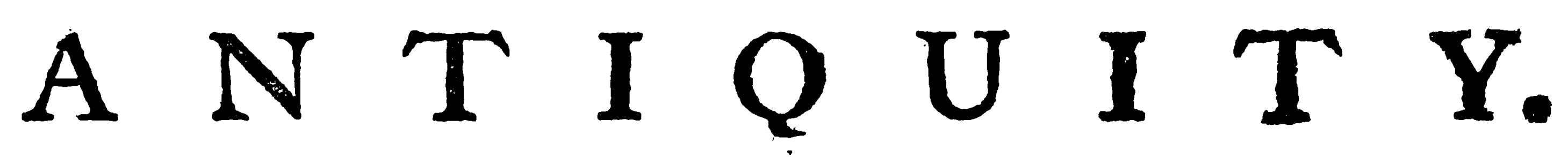

P U B L I S H E D B Y

\section{THE SOCIETY OF ANTIQUARIES OF LONDON.}

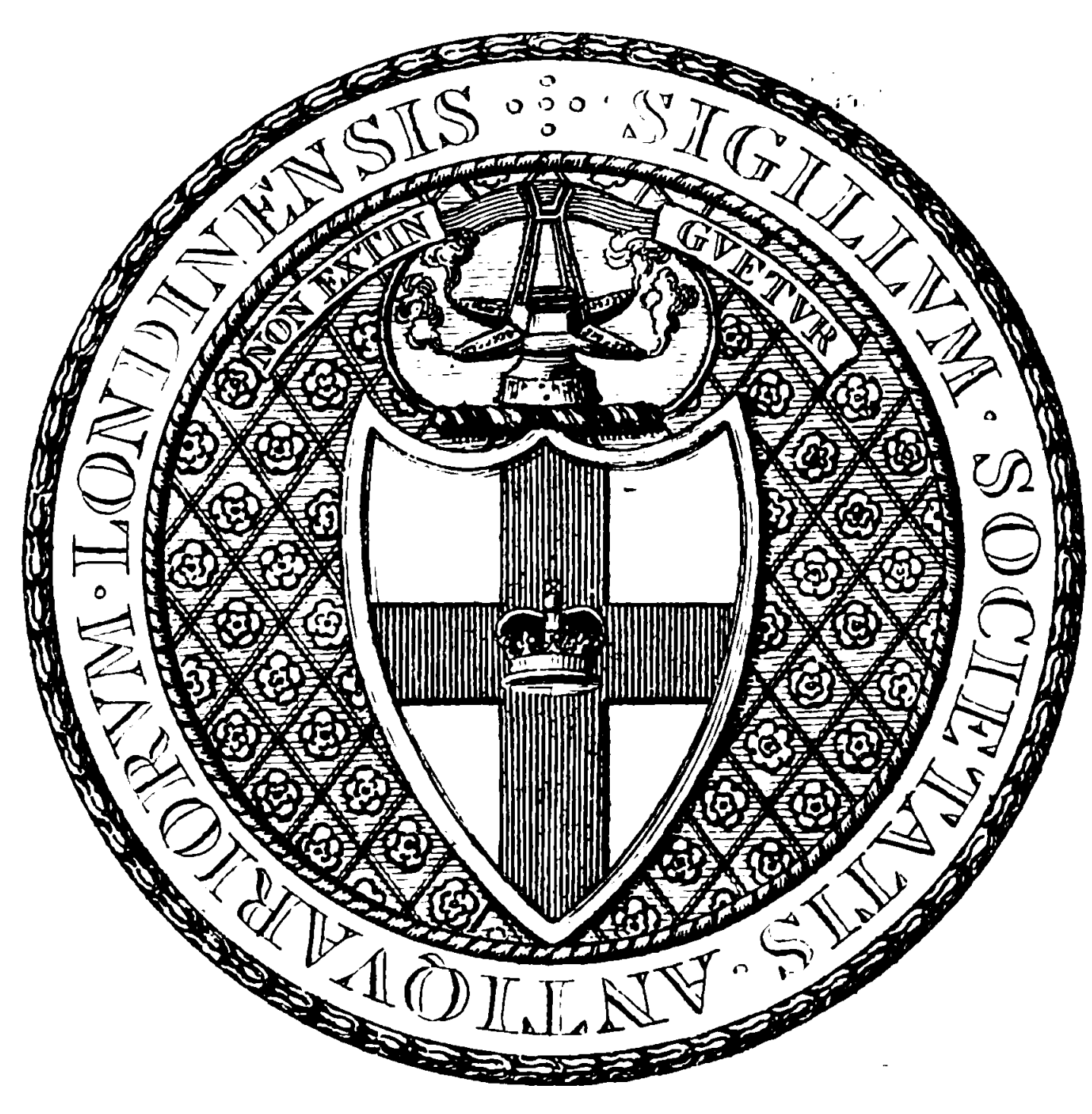

V O L. II.

Sold at the House of the Socrety, in Cha ancery-Lane; and by Meffieurs Wriss tove WHITE, ROBSON, BAKER and LEIGH, and BROWN。 


\section{[v]}

\section{$\mathrm{T}$ \\ A \\ $\mathbb{B}$ \\ L \\ $\mathrm{E}$ \\ O F

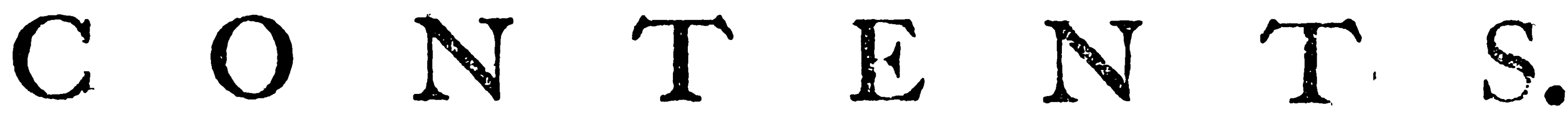

I. Obfervations on the Julia Strata, and on the Roman Siations, Forts, and Camps, in the Counties of Monmouth, Brecknock, Caermarthen, and Glamorgan. By the Reverend William Harris, Prebendary of Landaff, and Curate of Caireu. p. I

II. Obfervations on an Infcription at Spello. By F. Paffarini, a.td Roger Gale, Efquire.

p. 25

III. An Account of fome Antiquities found in Ireland; communicated by the Rigbt Rev. Richard Pococke, late Liord Biflop of Meath.

IV. Differtation on an ancient Cornelian. By the Reverend Mr. Hodgfon.

p. 42

V. An Account of a remarkable Monument in Penrith Church-yard, Cumberland. By Dr. Lyttelton, then Dean of Exeter. p. $4^{8}$ V.I. An Account of fome Antiquities difcovered on digging ints a large Roman Barrow at Elenborough, in Cumberland, 1763 . By the Reverend Mr. Head, Prebendary of Carlifle. p. 54 VII. Account of fome Roman Monumests found in Cumberland, 1766.

VIII. A Differtation on the Gule of Auguft, as mentioned in our

Statute Laws. By John Pettingal, D. D. r p. 60
IX. Objervations on the Miftakes of Mr. Lifle and. Mr. Hearne, in respect of King Alfred's Prefent to the Catbedrals. The late A 3 
Uje of the Stylus, or Nie'alline Pir. Mr. Wile's Conjecture concirning the famous fowel of King Alfred furtber purfized; Shewing it miglit pofilly be part of the Stylus fent by that King with Gregory's Paftoral, to the Monaftery at Athelney. By Mr. Pegge.

X. Objervations on the Aefte1. By the Rev. Dr. Milles, in a Letter to the Right Rev. the Lord Bifbop of Carlille, Prefident. p. 75 XI. Obfirvations on Mr. Peter Collinfon's Paper on the Round Toweers in Ireland, printed Vol. I. p. 305. By Owen Salufbury Brereton, Efq: F. R. S. and A.S.

p, 80 XII. Obfervations on the Round Tower at Brechin, in Scotland. By Richard Gough, Efq.

p. 83 XIIl. Tbe Bull-running, at Tutbury, in Staffordhire, confidered. By the Reverend Mr. Pegge.

p. 86 XIV'. Obfervations on an Altar, with a Greek Infcription, at Corbridge, in Northumberland. By the Rev. Dr. Pettingal. p. 92 $\mathrm{XV}$. Obfervations on the fame Infcription. By Dr. Adee, in a Letter to the Reverend Dr. Milles. p. 98 XVI. Obfervations on Dr. Percy's Account of Minftrels among the Saxons. By Mr. Pegge.

p. 100 X VII. An Account of the Monument commonly afcribed to Catigern. By Mr. Colebrooke.

p. 107

XVIII. Obfervations on Stone Hatchets. By Bifbop Lyttelton. p. I 8 XIX. Obfervations on Stone Hammers. By Mr. Pegge. p. 124 X.. Obfervations on an Infcription in the Cburch of Sunning-hill, Berks. By Dr. Milles, Dean of Exeter, and Prefident of the Society.

p. 129

XXI. Defcription of an ancient Font at Bridekirk, in Cumberland. By Bifrop Lyttelton.

p. 13 I

XXII. Obfervations on Caefar's Invafion of Britain; and more particularly bis Paffage acrofs the Thames, By the Hon. Daines

Barrington. 


\section{$\begin{array}{lllllllll}C & O & N & T & E & N & T & S .\end{array}$}

vii

Barrington. In two Letters, addrefid to the late Bifhop of Carlifle.

YXIII. Rumarks on the Time employed in Caefar's two Eupeditions into Britain. By the Reverend Dr. Owen, of St. Olave's, Hartftreet; communicated by the Honourable Daines Barrington. p. I 59 XXIV. Copy of the Draught of a Proclamation in the Year 1563, rilating to Perfons making Portraits of Queen Elizabeth. Froni the Original Dranght in the Paper-office, in the band-weriting of Secretary Cecil, with bis corrections, and among bis papers; communicated by Sir Jofeph Ayloffe, Bart.

XXV. A Differtation on the Crane, as a Difh ferved up at great Tables in England. By the Reverend Mr. Pegge.

XXVI. An Account of a Roman Sepulcbre found near York, in I 768 . By John Burton, 'M. $D$.

p. 177 XXVII. Extract of two Letters from Dr. John Burton, of York, to Dr. Ducarel, concerning Roman Antiquities difcovered in Yorkfhire, 1770. P: I8r XXVIII. The Confruction of the old Wall at Verolam. The Roman Bricks compared with the modern, \&c. In a Letter to Bijbop Lyttelton. By Mr. Webfter. $\quad \therefore \quad$ p. I 84 XXIX. Conjectures on an ancient Tomb in Salifbury Catbedral. By $M r$. Gough.

p. 188

XXX. An Account of an illuminated MS. in the Library of C. C. C. Cambridge. By the Reverend Mr. Ty fon," Fellow of the faid. College.

p. 194

XXXI. Some Remarks on Mr. Walpole's Hiftoric Doubts on the Life and Reign of King Richard the Third. By Robert Mafters, 17. D. ani Rector of Landbeach, in Cambridgethire. p. 198 XXXII. Obfervations on a Greek Infcription brought from Athens. By Daniel Wray; Efquire.

p. 2 I 6 XXXIII. 


\section{$\begin{array}{llllllllll}\text { viii } & C & O & N & T & E & N & T & S .\end{array}$}

XXXIII. Some Account of certain Tartarian Antiquities. In a Letter from Paul Demidoff, Efquire, at Peterfburg, to $M r$. Peter Collinfon, duted September 16, 1 764 . p. 222 XXXIV. Objervations on fome Tartarian Antiquities, defcribed in the preceding Article. By John Reinhold Forfter, F. A.S. p. 227 XXXV. A Defcription of the Sepulcbral Monument at New Grange, near Drogheda, in the County of Meatb, in Ireland. By Thomas Pownall, Efquire. In a Letter to the Reverend Gregory Sharpe, D. D. Mafter of The Temple. p. 236 XXXVI. A fuccinct and authentic Narrative of the Battle of Chefterfield, A. D. 1266, in the Reign of King Henry III. By $M r$. Pegge.

p. 276

XXXVII. Account of a Roman Pavement, with Wheat underneatb it, found at Colchefter. By the Reverend Dr. Griffith ; communicated by Edward King, Ef ; in a Letter to the Secretary. p. 286 XXXVIII. Mr. Lethieullier's Obfervations on Sepulcbral Monuments. In a Letter to James Weft, Efquire.

p. $29 \mathrm{I}$

XXXIX. A View of the ancient Confitution of the Englin Parliament. By Francis Maferes, Efquire, of the Inner Temple. p. $30 \mathrm{I}$ XL. Obgervations on Mr. Mafers's View of the ancient Conftitution of the Englifh Parlizment, by Charles Mellih, Equire. In a Letter to the Rev. Mr. Norris, Secretary to the Society of Anitiquaries.

$\mathrm{p} \cdot 34 \mathrm{r}$. XLA. Druidical Rerains in or near the Parifo of Halifax in Yorkih.re, difcovered and expluined, by the Rev. John Watfon, $M$. $A$. F.S. A. and Reitor of Stockpert iu Chethire.

XLII. Exiract of a Letter from the Rev. Mr. Bentham of 1.353 . the Dean of Exeter, concerning certain Difcoveries in Ely Minfter.

p. $3^{6} 4$. 